\title{
Knowledge about Care of Pregnant Mothers during the Covid-19 Pandemic
}

\author{
Faizah Betty Rahayuningsih*, Nurlaila Fitriani, Enita Dewi, Agus Sudaryanto, Sulastri Sulastri, Aulia Fitriannur Jihan \\ Department of Nursing, Faculty of Health Sciences, Universitas Muhammadiyah Surakarta, Surakarta, Indonesia
}

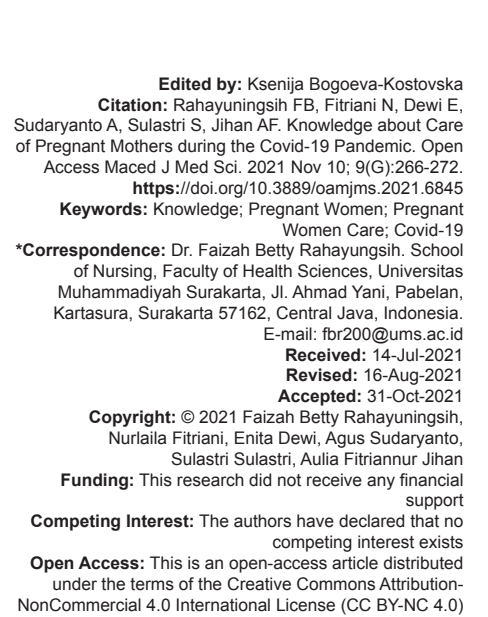

Abstract

BACKGROUND: China reported a case of pneumonia known as severe acute respiratory syndrome coronavirus to the World Health Organization of unknown cause in Wuhan City. Regulation Number 6 of 2018 concerning Health Quarantine regulates the basic provisions of the PSBB. Health services at the primary care are very limited, one of which is the care of pregnant women which is an activity that monitors and supports the health of normal pregnant women and detects normal pregnancies.

AIM: The purpose of this study was to describe the knowledge of pregnant women about the care of pregnant women during the COVID-19 pandemic at the Jayengan primary health care.

METHODS: This study uses a crosssectional design, the sample selection using purposive sampling with a sample of 40 respondents. Data collection was carried out using questionnaires made by researchers and filled out by respondents. Then, the data that have been collected is processed using software.

RESULTS: The results showed that the value of the sub-variable understanding of pregnant women with an average value of 100 , the sub-variable time of visit to pregnant women had an average value of 72.5 , the sub-variable of breast care for pregnant women had an average value of 79.16 , sub-variable nutrition variables in pregnant women have an average of 75.63 , the tetanus toxoid immunization sub-variable for pregnant women got an average value of 76.66 , the pregnancy check-up sub-variable got an average value of 97.5 , and the care of pregnant women who were confirmed to have COVID-19 got an average score of 55.93

CONCLUSION: The conclusion shows that the average knowledge level of respondents is sufficient.

\section{Introduction}

China reported a case of pneumonia to the World Health Organization of unknown cause in Wuhan City, Hubei Province on December 31, 2019. The coronavirus, scientifically known as severe acute respiratory syndrome coronavirus (SARS-CoV-2), was identified as the latest microorganism to cause infection. Humans called covid19 on January 9, 2020 [1].

The spread of this disease caused the WHO to declare an "Emergency" Public Health of International Importance" on 30 January 2020, which requires action to prevent the spread and reduce the occurrence of new infections [2]. It is known that SARS-CoV-2 is spread through droplets of respiratory secretions from symptomatic or asymptomatic individuals who carry the virus from contaminated substances. There is evidence that this pathogen is transmitted through feces [1]. The President of Indonesia, Joko Widodo, approved Government Regulation No. 21 of 2020 on March 31, 2020 regarding covid-19, PSBB is enforced if there are goods that enter and leave their respective areas must be approved by the relevant department. Regulation No. 6 of 2018 concerning Health Quarantine regulates the basic provisions of PSBB [3].

There is a knowledge gap due to SARS-CoV-2 during pregnancy. The number of infected pregnant women is proportionally smaller than the general population, but when infected, pregnant women become more susceptible to more severe manifestations of the disease. In this regard, based on the physiological changes that occur during pregnancy, the Brazilian Ministry of Health designated pregnant women as a risk group for COVID-19 in March 2020 [4].

In fact, many COVID-19 patients are not diagnosed with COVID-19, but on the way, they are only known to have COVID-19. As Parazzini (2020) said in another case after vaginal delivery, newborns of infected women tested positive. Gastrointestinal symptoms resolved within hours, and after 3 days he developed respiratory symptoms and was transferred to the neonatal intensive care unit where he recovered after 1 day of mechanical ventilation [5]. Symptoms that arise show a pattern of clinical features similar to nonpregnant adult patients. Pregnant women with recent COVID-19 are less likely to develop COVID-19-related fever and myalgia than nonpregnant women of reproductive age and potentially require more intensive care for COVID-19 [6].

Based on the results of a preliminary study through the distribution of questions with 15 pregnant women in the Jayengan Health Center area regarding knowledge about pregnant women's care, it was found that 9 people answered incorrectly on questions about breast care, 9 people answered wrongly on questions 
about Tetanus Toxoid (TT) immunization, 7 people answered incorrectly on questions about breast care, questions about nutrition fulfillment and 11 people answered the wrong questions on questions about pregnant women who were infected with COVID-19. Based on the data and preliminary study results obtained, researchers are interested in examining the description of pregnant women's knowledge about the care of pregnant women during the COVID-19 pandemic at the Jayengan Health Center, Serengan District, Surakarta City. The general purpose of this study was to describe the knowledge of pregnant women about the care of pregnant women during the COVID-19 pandemic at the Jayengan Health Center, Serengan District, Surakarta City. The specific objectives are: To describe the characteristics of respondents in the form of age, parity, education and occupation, to find out the knowledge of pregnant women about the care of pregnant women at the Jayengan Health Center including the understanding of pregnant women's care, when pregnant women visit, breast care, nutritional fulfillment, TT immunization, pregnancy checks,

\section{Method}

This type of research is descriptive quantitative and uses a cross-sectional approach. This research was conducted from January to March 2021 at the Jayengan Health Center, Serengan District, Surakarta City. The number of samples in this study was calculated using the Yamane formula so that the number of samples obtained was 40 respondents. The sampling technique used is purposive sampling. This study uses a single variable, namely the knowledge of pregnant women about the care of pregnant women. The measuring instrument used in data collection is a questionnaire made by the researcher himself.

\section{Results} as follows:

The results of data analysis from this study are

Based on the distribution Table 1, it can be explained that the most dominant age is the age of 26-35 years (early adulthood) which amounts to 17 respondents with a presentation of $42.5 \%$ and the lowest is the age of 17-25 (late adolescence) with a total of 10 respondents with a presentation of $25.0 \%$. Based on the distribution Table 1 above, the results of data processing of respondents' answers can be obtained, it can be explained that the most dominant parity is multigravida parity, totaling 31 respondents with
Table 1: Distribution of respondents by age, parity, education, and profession

\begin{tabular}{lll}
\hline Characteristics & $\mathrm{f}$ & $\%$ \\
\hline $17-25$ & 10 & $25.0 \%$ \\
$26-35$ & 17 & $42.5 \%$ \\
$36-45$ & 13 & $32.5 \%$ \\
Primigravida & 9 & $22.5 \%$ \\
Multigravida & 31 & $77.5 \%$ \\
Education & & \\
$\quad$ Elementary school & 3 & $7,5 \%$ \\
$\quad$ Junior High School & 6 & 15.0 \\
$\quad$ College & 19 & 47.5 \\
$\quad$ Senior High School & 12 & 30.0 \\
Occupation & & \\
$\quad$ House wife & 22 & 55.0 \\
$\quad$ Work & 18 & 45.0 \\
\hline
\end{tabular}

a percentage of $77.5 \%$, and the lowest is multigravida parity totaling 31 respondents with a percentage of $22.5 \%$.

The distribution of respondents based on the last education level of respondents, the most dominant is Senior High School (SMA)/Vocational High School, totaling 19 respondents with a percentage of $47.5 \%$ and the lowest is Elementary School with a total of 3 respondents with a percentage of $7.5 \%$. The distribution of respondents based on occupation is mostly housewives or not working, totaling 22 respondents with a percentage of $55.0 \%$, while the least work is working which amounts to 18 with a percentage of $45.0 \%$.

The specific purpose of this study was to determine the knowledge of pregnant women about the care of pregnant women at the Jayengan Public Health Center including the understanding of pregnant women's care, when pregnant women visit, breast care, nutritional fulfillment TT immunization pregnancy checks, and pregnant women who are confirmed to be COVID-19. The following will describe the average and standard deviation of each subvariable score for the level of knowledge of pregnant women:

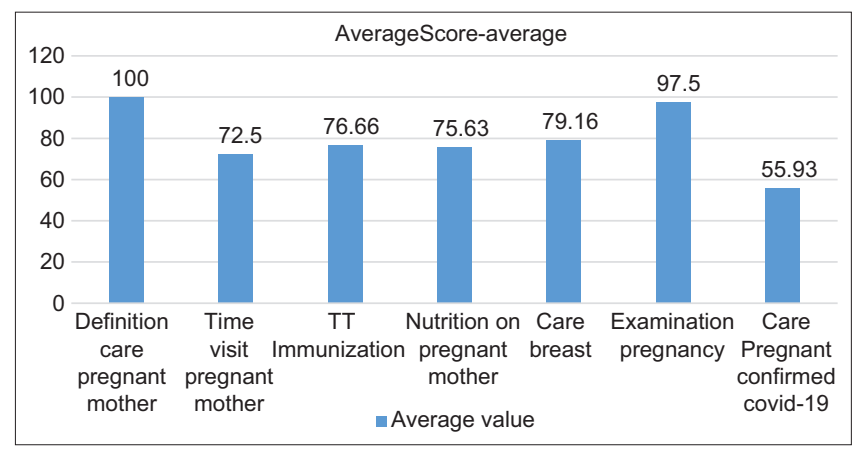

Figure 1: Average knowledge value

It can be seen from the results of the analysis of the Figure 1 above, from a scale of $0-100$. The lowest average score obtained from the knowledge of pregnant women is the sub-variable of pregnant women with confirmed COVID-19 with an average value of 55.93, followed by the subvariable during the visit of pregnant women which has an average value of 72.5 . Subvariable nutrition on nutrition in pregnant women has an average of 75.63 . The next subvariable about TT immunization got an average value of 76.66. The breast care subvariable has an average value of 79.16 , 
followed by the subvariables in the pregnancy checkup which got an average value of 97.5 , and the largest score was obtained by the subvariable understanding of pregnant women's care with an average value of 100 . The results of the analysis of the data above show that the knowledge of pregnant women about the care of pregnant women during the covid-19 pandemic classified as good.

Based on the Table 2 above, the respondents of this study have good knowledge as many as 6 respondents with a percentage of $15.0 \%$. Respondents with sufficient knowledge were 29 respondents with a presentation of $72.5 \%$, while for less knowledge, there were 5 respondents with a percentage of $12.5 \%$.

Table 2: Distribution of respondents based on general level of knowledge

\begin{tabular}{lll}
\hline Level of Knowledge & Frequency & $\%$ \\
\hline Good $(80.70-100 \%)$ & 6 & $15.0 \%$ \\
Enough $(67.91-80.69 \%)$ & 29 & $72.5 \%$ \\
Less $(<67.90 \%)$ & 5 & $12.5 \%$ \\
Total & 40 & $100.0 \%$ \\
\hline
\end{tabular}

The description of respondents' knowledge about the care of pregnant women by age at the Jayengan Health Center, Serengan District, Surakarta City can be seen in the following cross Table 3:

Table 3: Knowledge based on respondent's age

\begin{tabular}{|c|c|c|c|c|c|c|}
\hline \multirow[t]{2}{*}{ Category } & \multicolumn{6}{|c|}{ Respondent knowledge about maternity care } \\
\hline & \multicolumn{2}{|c|}{ Good } & \multicolumn{2}{|c|}{ Enough } & \multicolumn{2}{|c|}{ Less } \\
\hline Age & $\mathrm{n}$ & $\%$ & $\mathrm{n}$ & $\%$ & $\mathrm{n}$ & $\%$ \\
\hline $17-25$ & 0 & 0.0 & 8 & 80.0 & 2 & 20.0 \\
\hline $26-35$ & 5 & 29.4 & 11 & 64.7 & 1 & 5.9 \\
\hline $36-45$ & 1 & 7.7 & 10 & 76.9 & 2 & 16.7 \\
\hline \multicolumn{7}{|l|}{ Parity } \\
\hline Primigravida & 0 & 0.0 & 7 & 77.8 & 2 & 22.2 \\
\hline Multigravida & 6 & 19.4 & 22 & 71.0 & 3 & 9.7 \\
\hline \multicolumn{7}{|l|}{ Level of Education } \\
\hline Elementary school & 0 & 0.0 & 3 & 100 & 0 & 0.0 \\
\hline Junior High School & 1 & 16.7 & 3 & 50.0 & 2 & 33.3 \\
\hline Senior High School & 2 & 10.5 & 14 & 73.7 & 3 & 15.8 \\
\hline College & 3 & 15.0 & 29 & 72.5 & 5 & 12.5 \\
\hline \multicolumn{7}{|l|}{ Occupation } \\
\hline IRT & 3 & 16.7 & 13 & 72.2 & 2 & 11.1 \\
\hline Work & 6 & 15.0 & 29 & 72.5 & 5 & 12.5 \\
\hline
\end{tabular}

Results of the analysis, it is known that respondents in the age group of 17-25 years have the most sufficient knowledge with a total of 8 respondents or $80.0 \%$, the age group of 26-35 years has the most sufficient knowledge as many as 11 respondents or $64.7 \%$, the age group of $36-45$ years has the most sufficient knowledge of 10 respondents or $76.9 \%$. The results of the knowledge analysis based on parity showed that the parity Primigravida group had the most sufficient knowledge with 7 respondents $(77.8 \%)$, the multigravida parity group had the most sufficient knowledge amounting to 22 respondents (71.0\%).

Based on the results of the analysis, it is known that the elementary school education group has the most sufficient knowledge with 3 respondents $(100 \%)$, the junior high school education group also has sufficient knowledge with 3 respondents (50.0\%), the high school education group has the most knowledge which is sufficient amounting to 14 respondents (73.7\%) and the most tertiary education group also has sufficient knowledge of 9 respondents (75.0\%). The results of the knowledge analysis based on occupations showed that the most unemployed group had sufficient knowledge with a total of 16 respondents $(72.7 \%)$ and the working group had the most sufficient knowledge amounted to 13 respondents $(72.7 \%)$.

\section{Discussion}

In this study, the safe gestational age for the mother was 20-35 years. The vulnerable ages for pregnancy are those under 20 years old and above 35 years old. Physical conditions (especially genitals and psychological conditions) are not $100 \%$ ready for pregnancy and childbirth for people under 20 years of age. Those aged over 35 years are classified as high risk, because it is very possible to experience congenital abnormalities and complications during pregnancy and childbirth. Compared to the healthy reproductive age of 20-35 years, the egg quality of women over 35 years of age has decreased [6]. Pre-existing comorbidities, high maternal age, and high body mass index appear to be risk factors for severe COVID-19 [7].

In the study of Fagbamigbe et al. (2017), women aged 35-49 years had a higher risk of accessing ANC in 2003 and 2013 compared to women aged 15-19 years, whereas in 2008 women aged 25-34 years had a lower risk. The findings of this study are also similar to a study in 15 developing countries which found that younger women were less likely to use ANC services [8].

Based on the results of parity analysis of respondents, the minimum pregnancy to 1 and the maximum pregnancy to 5 , the parity of a pregnant woman can affect the psychological health of pregnant women, especially those who will face the delivery process. First parity is risky, because it is the result of the first fertilization of the uterus, and the elasticity of the uterine muscles is still limited by the growth of the fetus. The first parity still does not understand what happens during the labor process, and is often afraid, because when she enters an imaginary and scary labor process, she often hears stories about what will happen at gestational age [9]. Meanwhile, most pregnant women with parity more than 1 tend to be more mentally and psychologically prepared due to the labor process from previous pregnancies [10].

Based on the level of education, the most dominant is Senior High School/Vocational High School, totaling 19 respondents $(47.5 \%)$ and the lowest is Elementary School (SD) with 3 respondents $(7.5 \%)$. The level of education of pregnant women is a very important role in providing quality services to their babies, so that information about pregnancy care is needed to increase their knowledge [11]. Pregnant women with low levels of education sometimes do not get enough information about their health; they will 
not know how to maintain a good pregnancy. Highly educated people are usually more rational. Mothers who are well educated will undergo regular prenatal check-ups to maintain the health of themselves and their children in the womb.

The frequency distribution based on the occupational group is mostly unemployed, while the least is working. Work is related to mother's activities. The activities of busy mothers will take up time compared to mothers who do not work; examinations will be carried out less often or may not be carried out during pregnancy. Studies in Brazil also highlight that currently pregnant women should have more flexible work opportunities, being able to stop working when the gestational age is more than 28 weeks or when there are underlying risk factors or comorbidities. This precaution is necessary considering that being infected with COVID-19 during pregnancy tends to have negative impacts, such as spontaneous abortion, premature rupture of membranes, limited intrauterine growth, fetal distress, and premature labor and delivery [12].

The respondent's level of knowledge is good and sufficient knowledge. The level of good knowledge is the highest, while the level of sufficient knowledge gets a little value. The order of the average knowledge scores from the highest is the knowledge score of understanding pregnant women's care, antenatal care, breast care, TT immunization, nutrition for pregnant women, visit time for pregnant women, and the lowest is the care of pregnant women who are confirmed to be COVID-19. The knowledge score about the understanding of pregnant women's care is the highest because according to the puskesmas midwife, the puskesmas midwife has provided counseling about the importance of pregnant women care which in the care of pregnant women at the puskesmas provides integrated, comprehensive and quality antenatal services, so that mothers can have a healthy pregnancy, give birth safely and give birth to healthy babies, especially during the COVID-19 pandemic.

This is in accordance with the objectives of the Ministry of Health (2014) in providing antenatal services that are integrated, comprehensive, quality, family planning counseling and breastfeeding, minimizing "lost opportunities" for pregnant women, providing nutrition and health counseling for pregnant women, detecting early illness or disorder suffered by pregnant women, appropriate intervention for the disorder or disease as soon as possible, and the case can be referred to a medical institution in accordance with the existing referral system.

The score of knowledge about antenatal care is the second highest. This is because the information obtained by pregnant women from the puskesmas is quite clear, although the examinations carried out at the puskesmas do not use ultrasound and only use a physical examination and leopold examination. This examination does not reduce the low level of antenatal care to monitor physical, mental health and fetal growth and development. This is in accordance with Wahyuningsih's (2016) study to diagnose pregnancy by using the mother's abdominal examination technique to determine the position of the fetus by palpation called Leopold palpation, where Leopold palpation consists of 4 examinations [13].

Other researchers say the most established way of estimating fetal weight is the ultrasound method, as previously described and most often done with three measurements built into the algorithm. Other approaches such as MRI or soft tissue measurements have been shown to provide no additional benefit. The international percentile curve for estimated fetal weight, calculated after fetal studies in Anglo-Saxon countries and used to examine week-adjusted unborn fetal weight worldwide, may not be the right strategy as they pursue a one-size-fits-all policy near what is too large or too small [14].

The score of knowledge about breast care is quite sufficient, because the information obtained by mothers about breast care is still lacking; there are still many mothers who say that if the breasts are swollen, and they can produce milk. This is discussed in Anggraini (2010) that various problems of mothers who don't breastfeed because they don't breastfeed treatments that cause breast milk to not come out in turn result in breast engorgement [15]. Breast swelling or breast milk dams occur due to narrowing of the lactiferous ducts and then accumulate in the breast duct system. Other researchers say breast care is a special treatment effort through giving the mother's breast muscle stimulation by giving body massage. This activity is carried out in the morning and evening before bathing and is expected to stimulate the mother's mammary glands to produce breast milk. Physiologically, breast care is done by stimulating the breast to influence the posterior pituitary to release more oxytocin hormone through massage. When the ducts are stimulated by massage, the ducts will widen or soften by releasing oxytocin through the pituitary which plays a role in squeezing milk from the alveoli [16].

The score of knowledge about TT immunization is quite sufficient, according to the researcher's assumption, the information obtained by the mother is less, especially for mothers with more than 1 parity or multigravida. Although TT immunization has been carried out in the first pregnancy, immunization must be given during subsequent pregnancies. This is according to Eni (2019). Pregnant women receive at least 2 TT immunizations. One immunization does not provide immunity to newborns against tetanus, therefore infants $<1$ month old will experience tetanus due to umbilical cord injury. The protective effect appears when it is given at least 2 times with a minimum distance of 4 weeks, except if in the previous child's pregnancy or when the previous bride and groom had received TT 2 times, then TT was only given 1 time [17]. This is in line with the research of 
Awosan and Hassan (2018) about half of the respondents in their study who believe that TT immunization protects newborns and mothers from tetanus, and most believe that it is recommended only for pregnant women which shows a gap in the population's sensitivity to the disease as most of them obtained information about the disease through health workers (during antenatal clinic visits), who were likely to be more interested in vaccine promotion among their clients [18].

The score of knowledge about nutrition in pregnant women is quite sufficient, according to the researcher's assumption, mothers are still less informed that obesity in pregnant women causes high blood pressure. Obesity can be dangerous for sufferers, especially because of the high blood pressure that arises. The basic mechanism that is thought to play a role in the occurrence of hypertension in obesity is an increase in carbohydrate intake and fat will increase dedonation to become triiodothyronine which can stimulate - adrenergics, causing blood pressure to rise.

The knowledge score about the time of the visit of pregnant women is quite sufficient; the mother is still not informed about the minimum number of visits made in the third trimester. Visits of pregnant women during the pandemic are very limited, based on interviews with puskesmas midwives; pregnant women with gestational age above 30 weeks get an examination every 2 weeks. If you are pregnant with a gestational age of under 30 weeks who want to know the condition of the fetus, you can ask through the WhatsApp group that has been created from the puskesmas. This is in accordance with the 2018 Ministry of Health recommendation that the maternal health service plan in Indonesia recommends that pregnant women undergo at least 4 antenatal visits during pregnancy [19]

Foreign countries visit pregnant women using Telehealth, Telehealth is a way to optimize care and reduce the risk of exposure for pregnant women during the COVID-19 pandemic. Telehealth has previously been proposed as a suggestion to overcome obstacles related to the provision of medical services in disaster situations. Telehealth can be used in various medical professions to keep patients from receiving care in the COVID-19 environment while facilitating physical distancing (Aziz et al., 2020). Telehealth in addition to being recommended for the care of pregnant women in general, can be used for the following conditions, clinical scenarios and subspecialty services: Pregestational and gestational diabetes mellitus; Maternal cardiovascular disease; Hypertensive disorders of pregnancy include preeclampsia, gestational hypertension, and chronic hypertension; History of premature birth; genetic counseling; Maternal neurological condition [20].

The score of knowledge about the care of pregnant women who are confirmed to be COVID-19 is the lowest because knowledge about covid-19 itself is still minimal among the community, especially the knowledge of covid-19 related to pregnant women. A total of 22 respondents answered incorrectly on the questionnaire questions for pregnant women infected with COVID-19 showing a different pattern of symptoms from adult patients, in fact all people infected with COVID-19 have the same symptoms. Chen et al. research (2020), the pattern of clinical features of pregnant women with COVID-19 pneumonia shows similarities to non-pregnant adult patients. Common symptoms of COVID-19 pneumonia in pregnant women include fever, dry cough, loss of taste, and dyspnea, while less common symptoms are myalgia, malaise, sore throat, diarrhea, and fatigue.

Questionnaire questions about whether mothers who are confirmed to have COVID-19 can breastfeed their babies, 27 respondents answered incorrectly, mothers who were confirmed to have COVID-19 were allowed to touch and hold their babies, and 32 respondents answered incorrectly. Mothers who breastfeed confirmed COVID-19 in the Parazzini study (2020) in 10 cases breastfeeding was allowed, with women wearing surgical masks and 2 women having a new diagnosis of COVID-19 infection in the postpartum period and being breastfed without a surgical mask, the two newborns tested positive for Covid-19 on the $1^{\text {st }}$ and $3^{\text {rd }}$ days [21]. This is similar to the Indonesian Ministry of Health (2020) breastfeeding during the COVID-19 pandemic, and it is not transmitted through breast milk because the transmission of this virus comes from droplets, so mothers must avoid using eating utensils at the same time as the fetus [22]. Due to the close relationship between mother and child, mothers who want to breastfeed must wear masks to reduce the risk of transmission.

Questionnaire questions about pregnant women who carry out normal deliveries will transmit the Covid-19 virus, there are 29 respondents who answered incorrectly. Normal delivery will occur transmission through the mother's breathing because of the management of the breath that is carried out when the mother is straining. This is written in the research of Thomas et al. (2020) Cesarean section is the most common method of delivery for patients diagnosed with COVID-19 [23]. Several studies have shown that there is no adverse effect on fetal growth where pregnant women who are positive for COVID-19 give birth within 13 days of the onset of symptoms. Anecdotal evidence suggests that pregnant women do not appear to differ from the general population in terms of disease transmission. Currently, there is no evidence of vertical transmission from mother to child. The rate of premature birth in pregnant women with COVID-19 is higher than pregnant women without the disease [24]. Parazzini (2020) said elective cesarean section was performed in 18 cases, in 8 cases the indications were not related to Covid-19 infection, but in 10 cases the 
indications were worsening shortness of breath or other Covid-19-related symptoms in women who tried vaginal delivery [21].

The order of sufficient knowledge scores based on the age group from the highest is the 26-30 year age group with 11 respondents $(64.7 \%)$, while the lowest knowledge score is the 31-35 year age group with 1 respondent $(100 \%)$. This research is in accordance with the research of Oktaviani (2013), respondents aged 20-30 years have a good level of knowledge about the danger signs of pregnancy; this is in accordance with Yuliana et al. (2015) who said that age affects the way a person looks and thinks $[25,26]$. The older the age, the more constructive the response to problem. The younger a person faces a problem, the greater the influence on his self-concept. When determining the level of knowledge of pregnant women, age is considered as an underlying condition of a person's maturity and development. The order of knowledge scores based on parity from the highest is parity 2 , parity 1 , parity 3 , parity 4 , and the lowest is parity 5 .

This is in accordance with Wawan and Dewi (2014) that gravidity can be interpreted as the number of pregnancies a mother has experienced [27]. The more mothers experience pregnancy, the more knowledge the mother has about pregnancy, so that makes mother have experiences and knowledges about pregnancy. The order of knowledge scores is sufficient based on education from the highest, namely SMA/SMK, Universities, SMP and SD. This is in accordance with Sulistyawati (2011) that the education level of pregnant women is a very important role in providing quality services to their babies, so that information about pregnancy care is needed to increase their knowledge [11]. Pregnant women with low levels of education sometimes do not get enough information about their health; they will not know how to maintain a good pregnancy. Highly educated people are usually more rational. Mothers who are well educated will undergo routine pregnancy check-ups to maintain the health of themselves and their children in the womb

Characteristics of pregnant women based on work, most of them do not work, namely 22 respondents with good knowledge 3 respondents and 16 respondents with sufficient knowledge, pregnant women who work as many as 18 respondents with good knowledge 3 and sufficient knowledge 13 respondents. This is in accordance with Oktaviani (2013) research that mothers who do not work have a better level of knowledge than those who work [25]. The researcher assumes that mothers who do not work have more time at home, so they can directly get information through social media or tell stories to neighbors than working mothers who may have less time to seek information. The activities of busy mothers will take up time compared to mothers who do not work; pregnancy checks are carried out less often or may not be carried out during pregnancy.

\section{References}

1. Mascarenhas VH, Caroci-Becker A, Venâncio KC, Baraldi NG Durkin AC, Riesco ML. COVID-19 and the production of knowledge regarding recommendations during pregnancy: A scoping review. Rev Lat Am Enfermagem. 2020;28:e3348. https://doi.org/10.1590/1518-8345.4523.3348 PMid:32609284

2. World Health Organization. Prevention and Treatment of Pre-eclampsia and Eclampsia. Geneva: World Health Organization; 2011.

3. Humas RI. Inilah PP Pembatas Sosial Berskala Besar untuk Percepatan Penanganan COVID-19; 2020. Available from: https://www.setkab.go.id/inilah-pp-pembatasan-sosialberskalabesar-untuk-percepatan-penanganan-covid-19 [Last accessed on 2020 Dec 18]

4. Allotey J, Stallings E, Bonet M, Yap M, Chatterjee S, Kew T, et al. Clinical manifestations, risk factors, and maternal and perinatal outcomes of Coronavirus disease 2019 in pregnancy: Living systematic review and meta-analysis. BMJ. 2020;370:m3320. https://doi.org/10.1136/bmj.m3320 PMid:32873575

5. Fagbamigbe AF, Mashabe B, Lepetu L, Abel C. Are the timings and risk factors changing? Survival analysis of timing of first antenatal care visit among pregnant women in Nigeria (2003-2013). Int J Womens Health. 2017;9:807-19. https://doi. org/10.2147/IJWH.S138329

PMid:29133984

6. Mezy B. Manajemen Emosi Ibu Hamil. Yogyakarta: Serambi Semesta; 2016.

7. Goetzl L. Kehamilan Diatas 35 Tahun. Jakarta: Dian Rakyat; 2013.

8. Sulistyawati A. Asuhan Kebidanan Pada[ Masa Kehamilan]. Jakarta: Salemba Medika; 2011

9. Eni Rafika Devi Tria. Asuhan Kebidanan Kehamilan. Jakarta: Salemba Medika; 2019.

10. Preyer O, Husslein H, Concin N, Ridder A, Musielak M, Pfeifer C et al. Fetal weight estimation at term-ultrasound versus clinical examination with Leopold's manoeuvres: A prospective blinded observational study. BMC Pregnancy Childbirth. 2019;19(1):122. https://doi.org/10.1186/s12884-019-2251-5 PMid:30971199

11. Anggraini Y. Asuhan Kebidanan Masa Nifas. Yogyakarta: Pustaka Rihama; 2010.

12. Wahyuningsih HP, Tyastuti S. Praktikum Asuhan Kebidanan Kehamilan. Jakarta: Pusdik SDM Kesehatan; 2016.

13. Awosan K, Hassan M. Perception and utilization of tetanus toxoid immunization among pregnant women attending a tertiary Centre in North West Nigeria. J Drug Deliv Ther. 2018;8(6):119-24. https://doi.org/10.22270/jddt.v8i6.2032

14. Kemenkes RI. In: Kurniawan R, Yudianto Y, Hardhana B, Siswant T, editors. Profil Kesehatan Indonesia 2017. Jakarta: Kemenkes RI; 2018. Available from: http://www.depkes.go.id/resources/ download/pusdatin/profilkesehatanindonesia/profil-kesehatanindonesia-tahun-2017. [Last accessed on 2020 Dec 20].

15. Parazzini F. Vaginal delivery in SARS-CoV-2 infected pregnant women in Northern Italy: A retrospective analysis. Milan: Universitas Milan; 2020.

16. Chen H, Guo J, Wang C, Luo F, Yu X, Zhang W, et al. Clinical characteristics and intrauterine vertical transmission potential of COVID-19 infection in nine pregnant women: A retrospective review of medical records. Lancet. 2020;395(10226):809-15. https://doi.org/10.1016/S01406736(20)30360-3

PMid:32151335 
17. Dashraath P, Wong JL, Lim MX, Lim LM, Li S, Biswas A, et al. Coronavirus disease 2019 (COVID-19) pandemic and pregnancy. Am J Obstet Gynecol. 2020;222(6):521-31. https:// doi.org/10.1016/j.ajog.2020.03.021

PMid:32217113

18. Liang H, Acharya G. Novel Corona virus disease (COVID-19) in pregnancy: What clinical recommendations to follow? Acta Obstet Gynecol Scand. 2020;99(4):439-42. https://doi. org/10.1111/aogs.13836

PMid:32141062

19. Moller AB, Petzold M, Chou D, Say L. Early antenatal care visit: A systematic analysis of regional and global levels and trends of coverage from 1990 to 2013. LancetGlobHealth. 2017;5(10):977-83. https://doi.org/10.1016/S2214-109X(17)30325-X
PMid:28911763

20. Kemenkes RI. Pedoman Bagi Ibu Hamil, Ibu Nifas, dan Bay Baru Lahir: Di Era Pandemi COVID-19. Jakarta: Kemenkes RI; 2020.

21. Thomas B, Pallivalapila A, El Kassem W, Tarannum A, Al Hail F, Rijims M, et al. Maternal and perinatal outcomes and pharmacological management of COVID-19 infection in pregnancy: A systematic review protocol. Syst Rev. 2020;9(1):161. https://doi.org/10.1186/s13643-02001418-2 PMid:32682444

22. Yuliana Y. Dukungan Suami dalam Kehamilan dan persalinan yang Signifikan. Indonesia: Jurnal Universitas Esa Unggul; 2015.

23. Wawan D. Teori dan Pengukuran Pengetahuan, Sikap dan Perilaku Manusia. Yogyakarta: Nuna Medika; 2014. 